Article

\title{
The Resistance of Scots Pine (Pinus sylvestris L.) Half-sib Families to Heterobasidion annosum
}

\author{
Adas Marčiulynas *, Vaida Sirgedaitè-Šèžienè, Povilas Žemaitis and Virgilijus Baliuckas \\ Institute of Forestry, Lithuanian Research Centre for Agriculture and Forestry, Liepu str. 1, LT-53101 Girionys, \\ Kaunas District, Lithuania; Vaida.Seziene@mi.lt (V.S.-Š.); povilas.zemaitis@mi.lt (P.Ž.); \\ virgilijus.baliuckas@mi.lt (V.B.) \\ * Correspondence: adas.marciulynas@mi.lt
}

Received: 12 February 2019; Accepted: 21 March 2019; Published: 23 March 2019

\begin{abstract}
This study observed the genotypic variation among Scots pine (Pinus sylvestris L.) half-sib families' susceptibility to Heterobasidion annosum. Scots pine susceptibility was tested in 12 half-sib families by inoculating them with four different $H$. annosum strains. At two, six, and ten months after the inoculations, the susceptibility indicators (incidence rate, pathogen spread, and mortality rate) were compared and the total phenolic compounds (TPC) in the inoculated and control groups determined using the Folin-Ciocalteu method. Among half-sib families, significant differences were found for seedling mortality (range: $1.3 \%-21.2 \%$ ); however, the differences in incidence rate (range: $54 \%-77 \%$ ) and pathogen spread (range: $24-53 \mathrm{~mm}$ ) were not significant. The incidence rate among half-sib families correlated positively and significantly $(r=0.72, p<0.05)$ with the mortality rate, while the pathogen spread correlated negatively with mortality, although the correlation was not significant $(r=-0.29, p>0.05)$. The TPC comparison with susceptibility indicators showed that the half-sib families with lower susceptibility were characterized by the ability to increase TPC after inoculation compared to the control group. This tendency was most apparent in stems and roots six and two months after inoculation, respectively. Correlation analyses revealed that higher TPC in stems six months after inoculation determined a lower incidence rate $(r=-0.32, p<0.05)$, while higher Change in concentration of total phenolic compounds (TPC $\Delta$ ) indicated a lower pathogen spread $(r=-0.60, p<0.05)$. The lowest incidence of the pathogen was determined in half-sib families with the highest TPC $\triangle$ in the roots two months after inoculation. The lower susceptibility of Scots pine half-sib families is based on a combination of enhanced constitutive and inducible phenolic defense mechanisms. The data may facilitate the selection of Scots pine half-sib families with low susceptibility for breeding programs and forest management strategies.
\end{abstract}

Keywords: root rot; seedlings; inoculation; susceptibility; mortality rate; pathogen spread; phenolic compounds

\section{Introduction}

Scots pine (Pinus sylvestris L.) is the most widely distributed pine and is found throughout Eurasia. In the EU member states, it constitutes approximately $20 \%$ of the commercial forest area, and is of considerable importance as a timber producing species, especially in the north of Europe [1]. In Lithuania, Scots pine occupies 1/3 of all forested areas [2]. Although Scots pine does not have a lot of pests in Lithuania, a considerable number of overall pine stands are suffering from one of the most dangerous pathogens in the Northern Hemisphere-root rot (Heterobasidion annosum (Fr.) Bref.). This organism is considered an economically important pathogen of trees in the majority of northern temperate forests of Europe and North America [3]. Economic losses due to Heterobasidion infection in Europe are valued in the hundreds of millions of Euros annually [4]. In Lithuania, up to 300-400 ha of 
premature Scots pine stands are damaged by root rot each year [5]. H. annosum leads to an extensive mortality, and is particularly destructive in young plantations established on former agricultural land [6-8].

Heterobasidion spp. can spread in two main ways: airborne spores can infect recently cut stumps if the temperature is $>5^{\circ} \mathrm{C}[9,10]$, and healthy roots can become infected through root contact between healthy and infected roots [11,12]. Infection of roots results in reduced growth rates and premature death [13]. Scots pine stands begin to die 4-5 years after the first thinning, often resulting in open areas of up to 0.5 ha [14]. Fungal mycelium may remain viable in old stumps for decades, providing inoculum for the next generation of trees.

There are several ways to protect a new forest. It can be done through silvicultural, chemical, or biological control [15]. Reducing the number of thinnings, winter logging, and favoring mixed forests are all silvicultural actions that reduce opportunities for Heterobasidion to enter and spread within the stand [16]. Planting less susceptible tree genotypes is another option that actively reduces the spread of $H$. annosum. Experiments where Norway spruce and Scots pine were inoculated with H. annosum L. have consistently shown a significant difference in fungal sapwood colonization between different P. abies and P. sylvestris genotypes [11,17-20]. Up to $\sim 35 \%$ of this variation can be assigned to genotypic variation [21]. Inoculation experiments indicate that fungal extension is influenced by the host genotype to the same extent as other host traits, such as growth capacity, growth rhythm, and wood density $[18,19,22-24]$.

In woody plants, plant defense mechanisms comprise preformed and inducible physical and chemical barriers. Of the defense-related plant secondary metabolites, phenolic compounds are particularly important for quantitative resistance to fungal pathogens, which are the most important group of tree pathogens [25-27]. Conifers synthesize a large range of secondary phenolic metabolites, and some of them accumulate in high concentrations in the bark, roots, and needles [28,29]. The induction of phenolics by pathogens may occur locally in tissues surrounding infection sites, but also systemically, in distal parts of a tree. Pines contain a variety of secondary metabolites, including resin acids, terpenes, and phenolics, all of which have been implicated in resistance against natural enemies [26,30]. In Scots pine (Pinus sylvestris), stilbenes pinosylvin (PS) and pinosylvinmonomethylether (PSME) occur constitutively in the heartwood. These chemicals are likely involved in the considerable resistance of pine heartwood against fungal colonization, probably as a result of their dual activity as fungicides and antioxidants [31,32]. Among the conifer phenolics, stilbenes have been most frequently studied in the context of induced resistance to pathogens. In Scots pine, the stilbenes PS and PSME, and several flavonoids, often accumulate locally in the reaction zone after fungal infection [33,34], and can be induced systemically in the needles [35]. These compounds were induced by different challenges (e.g., by wounding), indicating that the response was nonspecific. Some low molecular weight phenolic compounds may function as precursors for other defensive compounds (e.g., lignin [36]), or they may confer resistance by synergistic effects, or challenge the pathogen due to variable concentration levels [37,38].

Some authors report that variation of plant secondary metabolites depends upon both genetic and environmental factors [39-41]. In coniferous trees, associations have been reported for several phenotypic traits, including wood properties [42-45], growth and wood chemistry [46], serotiny [47], carbon isotope discrimination [48,49], cold hardiness, and bud set timing [50,51], but rarely for cellular phenotypes (e.g., metabolite concentrations) [52] or disease resistance [53]. However, the genetic basis of variation in metabolite concentrations and its relation to fungal infections in Scots pine trees is largely unknown.

In order to fill this knowledge gap, a multifunctional experiment was designed to reveal the implications and interactions between morphological traits, half-sib families, different H. annosum strains, mortality, and the content of total phenolic compounds (TPC) of Scots pine seedlings. The aim of this study was to evaluate the variation of TPC in different parts of three-year-old Scots pine seedlings inoculated with $H$. annosum in order to determine the resistance of half-sib families to a 
fungal pathogen. Hence, we focused on three main questions: (1) does H. annosum infection frequency, spread in the stem wood, and seedling mortality rate vary among different Scots pine genotypes? (2) Do genotypes differ on initial TPC and plant capacity to increase TPC due to infection? (3) Does TPC correlate with infection frequency, pathogen spread, and seedling mortality rate among genotypes?

\section{Materials and Methods}

\subsection{Isolates of Heterobasidion annosum}

Heterobasidion annosum strains were isolated from living Scots pine trees from four different geographical locations in southern Lithuania (Figure 1). Sample points were established in stand gaps induced by $H$. annosum outbreaks and spaced from 7 to 10 kilometers apart. It is known that this distance is sufficient to select different $H$. annosum strains [54]. At each sample point, 1-3 living trees were selected. Trees were sampled by taking an increment borer core at stump level. A piece of the obtained wood cylinder was surface-sterilized with a gas flame, placed on $9 \mathrm{~cm}$ Petri dishes containing Hagem agar medium [55], and incubated at $20^{\circ} \mathrm{C}$ until sufficient mycelium had grown out to enable subcultures to be made [56]. Pure H. annosum culture was then transferred to Hagem agar medium slants for long-term storage at $4{ }^{\circ} \mathrm{C}$. The pure cultures were identified by Woodward et al. [4].

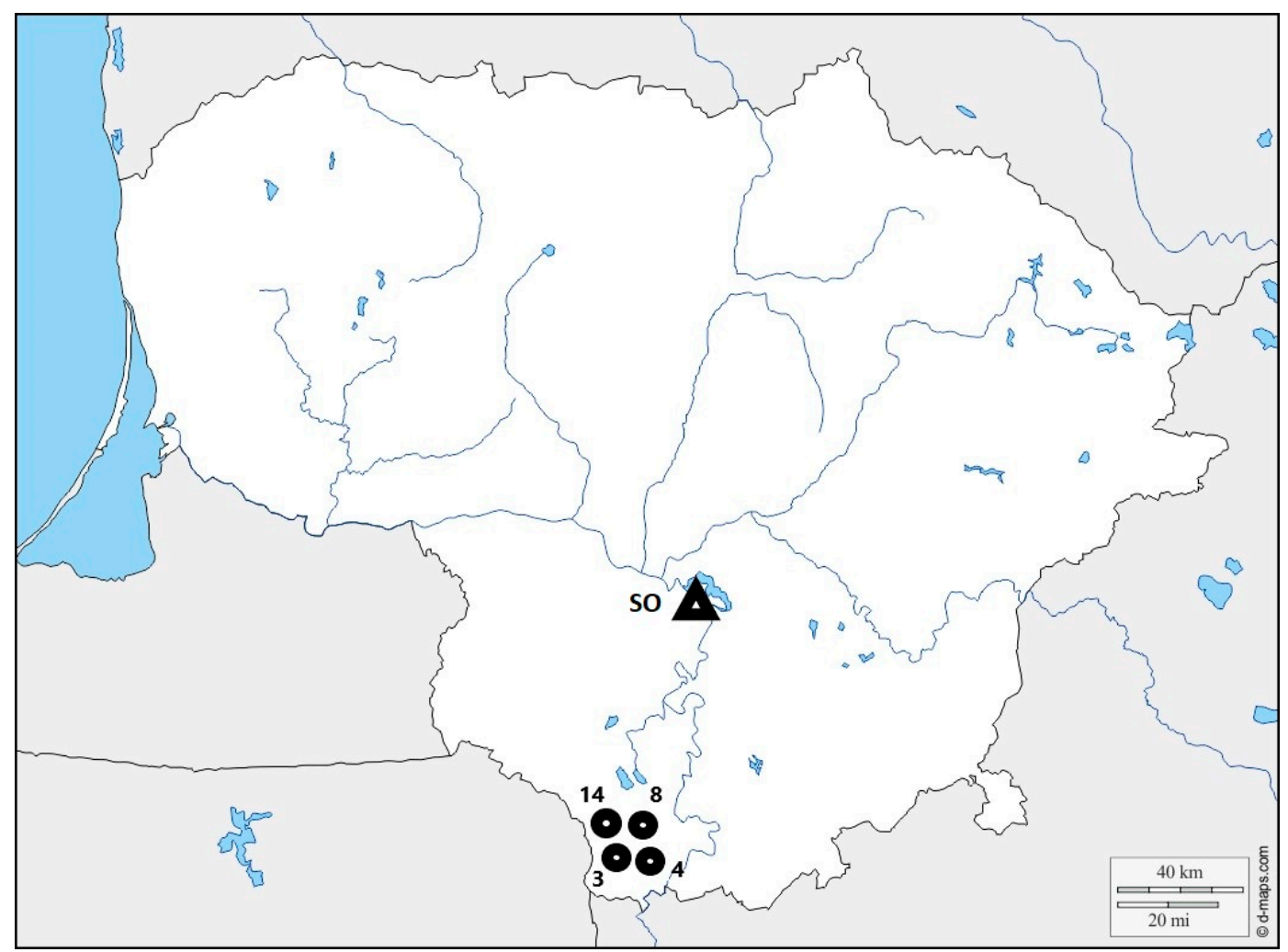

Figure 1. Map of Lithuania showing the study site: potentially resistant to root rot Scots pine clones seed orchard ( $\mathrm{SO}-54^{\circ} 53^{\prime} 0.37^{\prime \prime} \mathrm{N} ; 4^{\circ} 4^{\prime} 20.45^{\prime \prime} \mathrm{E}$ ) and H. annosum strains isolating points (3 strain

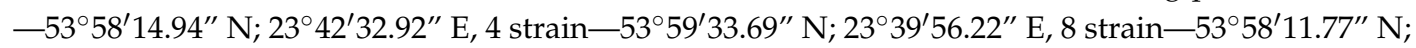
$23^{\circ} 37^{\prime} 3.47^{\prime \prime}$ E, 14 strain-54 $10^{\prime} 20.02^{\prime \prime}$ N; $23^{\circ} 39^{\prime} 57.38^{\prime \prime}$ E).

All isolates used in the inoculation experiments were maintained in the culture collection of the Laboratory of Forest Protection and Game Management, Institute of Forestry, Lithuanian Research Centre for Agriculture and Forestry, Girionys, Lithuania. 


\subsection{Inoculation and Inspection Methods}

The plant material for the inoculation experiment was from a Scots pine seed orchard established in 1974-1977 in the Vaišvydava forest district of the Dubrava Forest Research Station (now the Public Institution Dubrava Experimental and Training Forest Enterprise). The seed orchard was established from local Scots pine genotypes, classified as naturally less susceptible to H. annosum infection (externally healthy trees from gaps induced by H. annosum outbreaks). Seeds were collected from 12 pine genotypes to grow plant material for 12 half-sib families (Figure 1). A total of 1200 healthy three-year-old P. sylvestris seedlings without any visible symptoms were selected for the inoculation experiment; 100 seedlings were in each of the 12 half-sib families. The inoculum was prepared using a procedure described by Swedjemark and Stenlid [57] and Zaluma et al. [24]. Small pieces $(1.0 \mathrm{~cm} \times 0.3 \mathrm{~mm} \times 0.2 \mathrm{~mm})$ of autoclaved pine wood were placed on fresh cultures of each $H$. annosum strain and incubated for 20 days at room temperature in the dark until the woody pieces were overgrown by the fungal mycelium.

The experiment started in mid-November 2017. A 15-20 mm long incision was made on the stem $3 \mathrm{~cm}$ from stump level using a sterile scalpel and without removing the bark. The inoculum with fungal mycelium was inserted into the incision, and the lesion was sealed with Parafilm tape. Control inoculations were made using small, sterile wood pieces $(12 \times 20 \times 4 \mathrm{~mm})$. A total of 960 P. sylvestris seedlings were inoculated with four different $H$. annosum strains ( 240 pine seedlings were inoculated per isolate; 20 seedlings in one Scots pine half-sib family), and 240 seedlings were inoculated with sterile wood pieces (control) (Figure 1). The plants were grown outdoors in 5-liter plastic pots filled with peat substrate, under a watering and fertilization regime established in forest nurseries.

Seedling vitality and incidence rate of $H$. annosum (fungal growth) infection were examined at three time periods over the course of 2018: at two months after inoculation (i.e., inspection I), at the beginning of vegetation six months after inoculation (inspection II), and at the end of vegetation (inspection III), ten months after inoculation. For each inspection period, three visually healthy and all dead seedlings were taken from each variant (more than 180 seedlings in total). For each of these samples, a $20 \mathrm{~cm}$ length of stem was cut into $5 \mathrm{~cm}$ pieces, split in half, and placed in separate sealed bags. After three weeks incubation at room temperature, the samples were checked for mycelia, conidiophores, and conidia formation characteristic of H. annosum [58].

\subsection{Quantification of Phenolic Compounds}

Samples of the seedlings' roots, stems, and needles were collected from three biological replicates from both inoculated and control groups during the three time periods described above (Total samples number: 12 Scots pine half-sib families $\times 4$ different $H$. annosum strains and 1 control $\times 3$ biological replicates $\times 3$ different seedlings' parts $=540$ samples during one time period). The $500 \mathrm{mg}$ of fresh needles, stem wood, and root samples were stored at $-20^{\circ} \mathrm{C}$ until bioactive substances were analyzed. Before analysis, the samples were homogenized by A 11 basic Analytical mill (Laboratory Equipment, Staufen, Germany). The homogenized material was shaken with $10 \mathrm{~mL}$ of $75 \%$ methanol for $24 \mathrm{~h}$ at room temperature using a Kuhner Shaker X electronic shaker (Adolf Kühner AG, Birsfelden, Switzerland). The extracts were filtered through Whatman no. 1 filter paper.

Total phenolic content (TPC) of extracts was assessed by using the Folin-Ciocalteu (FC) reagent method [59]. Then, $0.1 \mathrm{~mL}$ of extract was mixed with $0.1 \mathrm{~mL}$ of $2 \mathrm{~N} \mathrm{FC}$ reagent and $2.5 \mathrm{~mL}$ of distilled water. After $6 \mathrm{~min}, 0.5 \mathrm{~mL}$ of $20 \% \mathrm{Na}_{2} \mathrm{CO}_{3}$ was added. The extracts were mixed and allowed to stand for $30 \mathrm{~min}$ before measuring. The absorbance was measured after $30 \mathrm{~min}$ at $760 \mathrm{~nm}$ using the T80 UV-VIS spectrophotometer (PG Instruments, Leicestershire, UK). All determinations were performed in triplicate. The standard calibration curve was plotted $\left(R^{2}=0.9989\right)$ using $0.015625,0.0625,0.125,0.25$, $0.375,0.5,0.75$, and $1.0 \mathrm{mg} / \mathrm{mL}$ chlorogenic acid solutions. The total phenolic content was expressed as chlorogenic acid equivalents in $\mathrm{mg} / 100 \mathrm{~g}$ of fresh material (CAE $\mathrm{mg} / \mathrm{mL}$ ). 


\subsection{Statistical Analysis}

Except for growth traits, plots of residuals for all remaining traits showed deviations from the normal distribution. No transformation of the original data was done. Instead the SAS GLIMMIX (generalized linear mixed models) procedure ( (Kenward-Roger method) DDFM $=$ KR option, which applies the standard error and degrees-of-freedom correction [60]) was used for calculation of variance components (SAS Institute Inc. 2002-2012, version 9.4, Cary, NC, USA). Model 1 for the statistical analyses without interaction:

$$
Y_{i j k}=\mu+S_{i}+F_{j}+E_{i j k}
$$

where $\mu$ is the grand mean, $S_{i}$ is the random effect of strain $\mathrm{i}, F_{j}$ is the random effect of family $\mathrm{j}$, and $E_{i j k}$ is the residual error.

Model 2 for the statistical analyses with interaction included:

$$
Y_{i j k}=\mu+S_{i}+F_{j}+S F_{i j}+E_{i j k}
$$

where $\mu$ is the grand mean, $S_{i}$ is the random effect of strain $\mathrm{i}, F_{j}$ is the random effect of family $\mathrm{j}, S F_{i j}$ is the random effect of strain $i$, family $j$, and their interaction, $E_{i j k}$ is the residual error.

F-tests of the variance components (Type III) were obtained from analyses of the GLIMMIX procedure in SAS (V9.4 software packages, SAS Institute Inc., Cary, NC, USA). Pearson correlations were calculated using the SAS CORR procedure.

TPC $\Delta$ is described as the differences between TPC in control group seedlings and inoculated seedlings.

The NPAR1WAY procedure, which performs nonparametric tests, was used for pairwise comparisons of H. annosum strains in between and with control. The DSCF option was applied, which computes the Dwass, Steel, Critchlow-Fligner multiple comparison analysis based on pairwise two-sample Wilcoxon comparisons. The DSCF statistic for a pair of samples was computed as two-sample standardized Wilcoxon statistic (Z).

\section{Results}

\subsection{Incidence Rate, Pathogen Spread, and Pine Seedlings Mortality}

The highest infection incidence rate was found in stem wood $0-5 \mathrm{~cm}$ from the inoculation site: two, six, and ten months after inoculation, infection incidence rate was $79.3 \%, 72.4 \%$, and $63.0 \%$, respectively (Figure 2). The infection incidence rate decreased with increasing distance from the inoculation site. Our results show that $H$. annosum mycelium growth is time dependent. During inspection after two months, infection incidence in stem wood had spread a distance of 5-10 cm from the inoculation site, with a $6.2 \%$ infection incidence rate at this distance. During inspection after 6 months, mycelium had spread a distance of $10-15 \mathrm{~cm}$ from the inoculation site, with an infection incidence rate of $2 \%$. The inspection after 10 months showed that mycelium had spread a distance of $15-20 \mathrm{~cm}$ from the inoculation site, with an infection incidence rate of $8.2 \%$. A distance of $15-20 \mathrm{~cm}$ was approximately one-third of the average seedling height at the inspection after 10 months. The infection incidence rate in dead seedlings was more than three times lower at the inoculation site $(0-5 \mathrm{~cm})$, however, apparently abundantly higher in more distant $(5-10 \mathrm{~cm}, 10-15 \mathrm{~cm}$, and $15-20 \mathrm{~cm})$ parts of stem. 


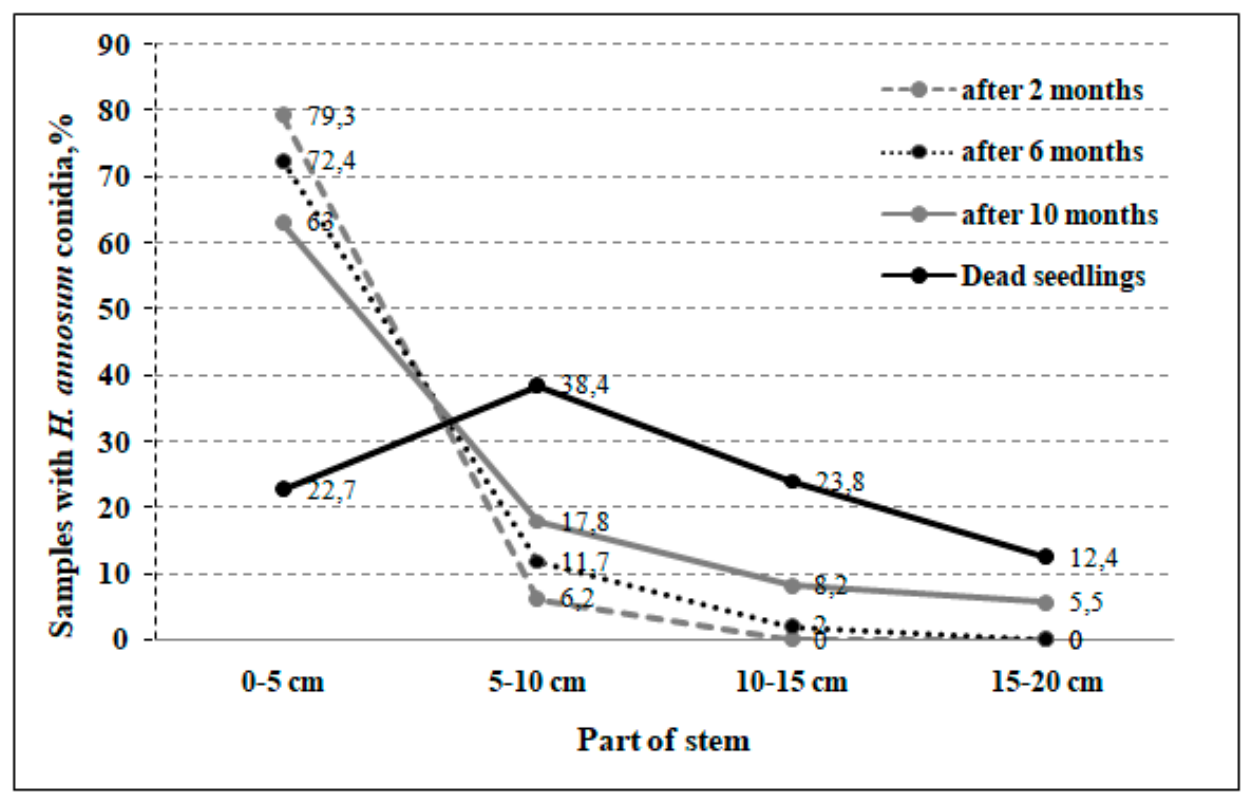

Figure 2. H. annosum incidence rate and growth in seedlings stem wood two, six, and ten months after inoculation the points represent four strains averages in $12 \mathrm{Scots}$ pine half-sib families. Incidence rate and pathogen growth in dead seedlings presented as average from all dead seedlings 10 months after inoculation.

At the time of inoculation, the mean height of the control seedlings was $55.1 \pm 0.3 \mathrm{~cm}$, which was almost equal to the inoculated trees mean height of $54.7 \pm 0.3 \mathrm{~cm}$. The stem diameter at the inoculation site (c. 1-2 cm from the soil surface) for all trees was the same: $9.7 \pm 0.07 \mathrm{~mm}$. After the vegetation period (10 months after inoculation), the height of inoculated seedlings with $H$. annosum was $75.7 \pm 0.3 \mathrm{~cm}$, while the height of the control trees was $70.3 \pm 0.4 \mathrm{~cm}$. The mean stem diameter of inoculated trees at the inoculation site was $12.4 \pm 0.1 \mathrm{~mm}$ and the mean stem diameter of the control trees was $11.11 \pm 0.12 \mathrm{~mm}$. The results showed that trees with $H$. annosum infection after the vegetation period (10 months after inoculation) were, in general, slightly taller and had a larger stem diameter than the control trees. Pairwise comparisons of H. annosum strains in between and with control for infection incidence rate and $H$. annosum mycelium spread after six months are presented in the Table 1. Control significantly differed from the treatments for all traits, so in the Table 1 are shown only those traits, where significant differences were observed between the strains as well.

The results of the seedlings' mortality show large differences between half-sib families, varying from $1.3 \%$ to $21.2 \%$ (Figure 3). The lower variability was observed for pathogen spread (from $24-53 \mathrm{~mm}$ on average), and incidence rate (from $54 \%-77 \%$ on average). The lowest mortality was found in seedlings of No. 1, 12, and 9 half-sib families; the lowest pathogen spread in No. 3, 9, and 4 half-sib families; and the lowest incidence rate in No. 9, 10, and 3 half-sib families. The incidence rate among half-sib families correlated positively and significantly $(r=0.52, p<0.05)$ with mortality, while pathogen spread in surviving plants correlated negatively with mortality although correlation was not significant $(r=-0.29, p>0.05)$. Height and diameter did not correlate with mortality or pathogen spread length, except weak correlation of stem diameter with infected and dead plants $(r=0.19, p<0.01)$. The variance component of strain for pathogen spread was $10.1 \% \pm 8.9 \%$ (the ratio to residuals $=0.114$ ) and significant, while the family component was negligible (model 1). The opposite tendency was seen for plant mortality, where the family variance component was $6.7 \% \pm 5.4 \%$ (the ratio to residuals $=0.072$ ) and significant. If family $\mathrm{x}$ strain interaction was added to the statistical model 2 , the family $\mathrm{x}$ strain variance component was the largest for pathogen spread $(14.9 \% \pm 9.3 \%$, the ratio to residuals $=0.20)$. The results of family effect for mortality did not change using both statistical models. 
Table 1. Pairwise comparison of H. annosum strains in between and with control (sample size $n=36$ ).

\begin{tabular}{|c|c|c|c|}
\hline Pairs of Treatments for Comparison & Wilcoxon Z & DSCF Value & $\operatorname{Pr}>$ DSCF \\
\hline \multicolumn{4}{|c|}{ Variable: incidence rate of $H$. annosum infection after six months } \\
\hline Control vs. strain No. 3 & -6.92 & 9.79 & $<0001$ \\
\hline Control vs. strain No. 4 & -6.33 & 8.96 & $<0001$ \\
\hline Control vs. strain No. 8 & -4.86 & 6.88 & $<0001$ \\
\hline Control vs. strain No. 14 & -7.54 & 10.65 & $<0001$ \\
\hline Strain No. 3 vs. strain No. 4 & 0.83 & 1.17 & 0.9225 \\
\hline Strain No. 3 vs. strain No. 8 & 2.70 & 3.82 & 0.0534 \\
\hline Strain No. 3 vs. strain No. 14 & -0.98 & 1.38 & 0.8662 \\
\hline Strain No. 4 vs. strain No. 8 & 1.92 & 2.72 & 0.3063 \\
\hline Strain No. 4 vs. strain No. 14 & -1.77 & 2.51 & 0.3887 \\
\hline Strain No. 8 vs. strain No. 14 & -3.56 & 5.03 & 0.0034 \\
\hline \multicolumn{4}{|c|}{ Variable: H. annosum mycelium spread after six months } \\
\hline Control vs. strain No. 3 & -6.72 & 9.51 & $<0001$ \\
\hline Control vs. strain No. 4 & -6.24 & 8.82 & $<0001$ \\
\hline Control vs. strain No. 8 & -4.86 & 6.88 & $<0001$ \\
\hline Control vs. strain No. 14 & -7.43 & 10.50 & $<0001$ \\
\hline Strain No. 3 vs. strain No. 4 & 1.31 & 1.85 & 0.6880 \\
\hline Strain No. 3 vs. strain No. 8 & 3.49 & 4.94 & 0.0044 \\
\hline Strain No. 3 vs. strain No. 14 & 0.68 & 0.96 & 0.9615 \\
\hline Strain No. 4 vs. strain No. 8 & 2.41 & 3.40 & 0.1134 \\
\hline Strain No. 4 vs. strain No. 14 & -0.93 & 1.32 & 0.8848 \\
\hline Strain No. 8 vs. strain No. 14 & -3.77 & 5.34 & 0.0015 \\
\hline
\end{tabular}
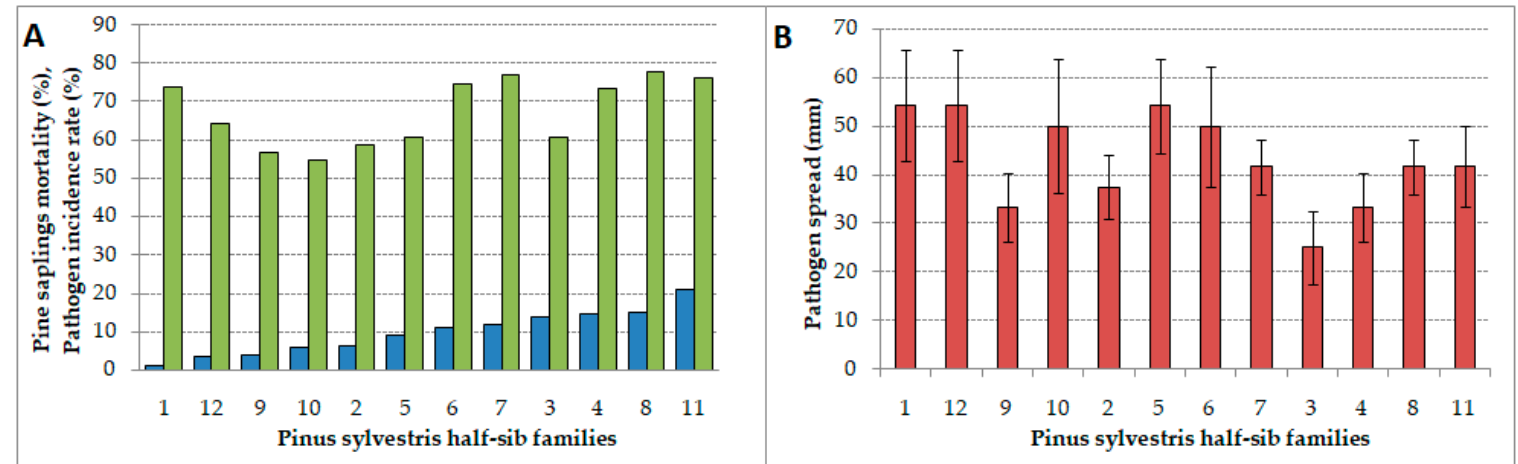

Figure 3. (A) Pine saplings mortality (\%; blue bar), incidence rate (\%; green bar) and (B) pathogen spread $(\mathrm{mm})$, in 12 Scots pine half-sib families. Mortality (\%) presented as total dead seedlings percentages 10 months after inoculation. Incidence rate (\%) presented as average incidence rate 2, 6 , and 10 months after inoculation. Pathogen spread $(\mathrm{mm})$ presented as average pathogen spread 2, 6, and 10 months after inoculation (Standard errors are shown above the bars).

\subsection{The Relationship between TPC Accumulation and Susceptibility to H. annosum}

The amount of TPC in Scots pine needles, stem wood, and roots was determined during three different periods (two, six, and ten months after inoculation) in order to compare the chemical resistance of different Scots pine half-sib families to the pathogen H. annosum. The TPC in the parts of seedlings significantly differed in both inoculated and control groups; the highest TPC was observed in the needles, with the lowest in roots (Figure $4 \mathrm{a}-\mathrm{c}$ ). 

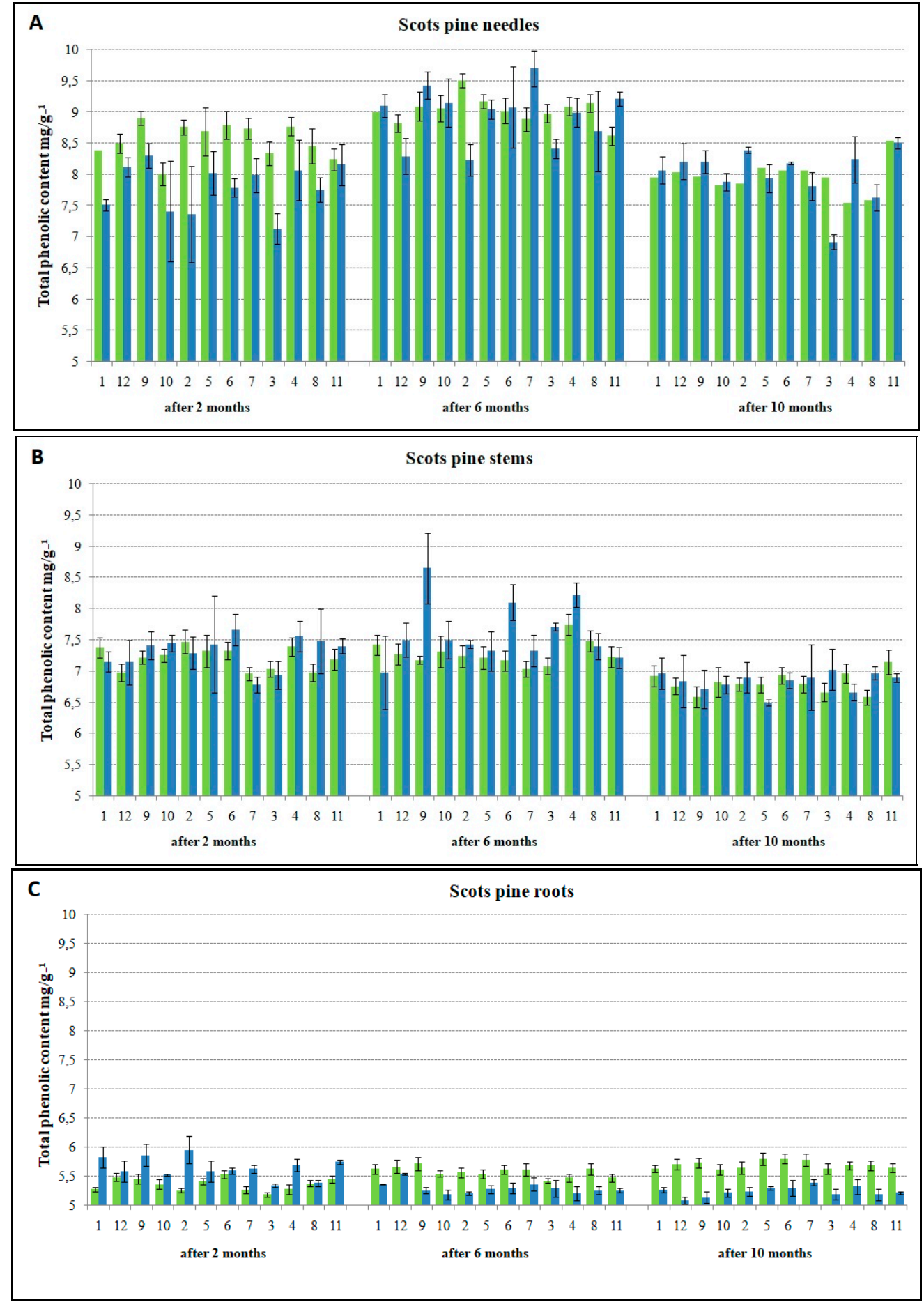

Figure 4. Concentration of total phenolic compounds (TPC) in 12 inoculated (blue column) and control (green column) group Scots pine half-sib families two, six, and ten months after inoculation: (a) TPC in needles; (b) TPC in stems, and (c) TPC in roots.

TPC concentration (Figure 4a-c) compared with susceptibility indicators (incidence rate, spread, and mortality; Figure 3) showed that the half-sib family with lower susceptibility was characterized by the ability to increase TPC after inoculation compared to the control group. This tendency was most apparent in stems six months after inoculation (No. 9) and roots two months after inoculation (No. 1) (Figure 5a-c). 


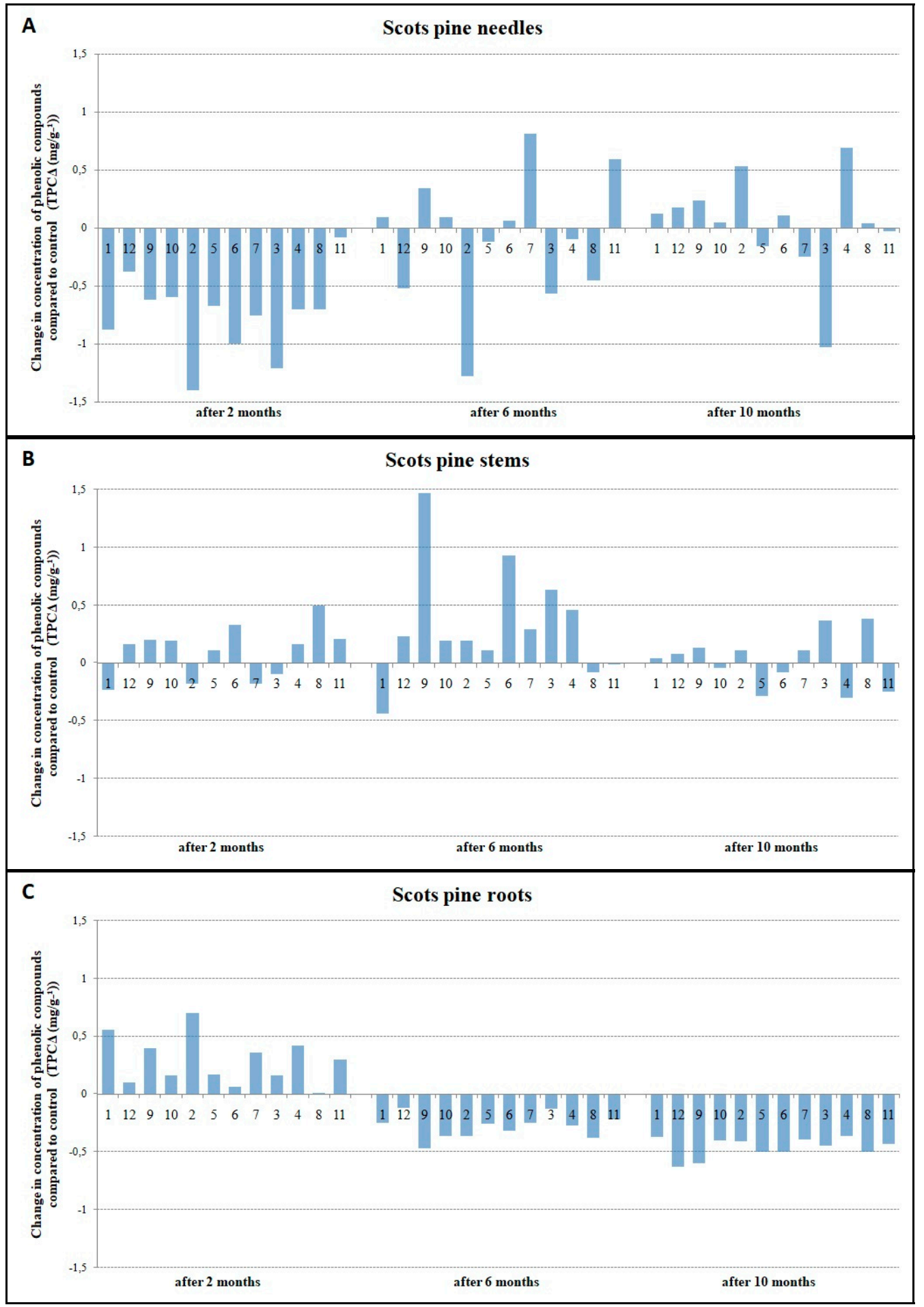

Figure 5. Change in concentration of total phenolic compounds (TPC $\Delta$ ) two, six, and ten months after inoculation compared to the control group of 12 Scots pine half-sib families: (a) TPC $\Delta$ in needles; (b) TPC $\triangle$ in stems and (c) TPC $\triangle$ in roots.

Six months after inoculation, the accumulation of TPC in stems strongly increased (TPC $\Delta$ was $1.4 \mathrm{mg} / \mathrm{g}^{-1}$ ) in No. 9, the half-sib family with lower susceptibility (Figure $4 \mathrm{~b}$ ). This family also had the lowest mortality rate compared to more susceptible half-sib families. Correlation analyses revealed that higher TPC in stems six months after inoculation correlated with a lower incidence rate $(r=-0.32, p<0.05)$ and lower pathogen spread $(r=-0.32, p<0.05)$. The families (No. 2 and 9) 
with lower pathogen spread showed an increase in the accumulation of TPC in the roots two months after inoculation (Figure 5c). TPC $\Delta$ in stems six months after inoculation correlated negatively and significantly with the pathogen spread $(r=-0.60, p<0.05)$; families with lower pathogen spread significantly increased the accumulation of TPC. The lower pathogen spread in the stems and higher TPC in the roots could be the main factor in the decrease of the mortality of half-sib families (Figure 2). Meanwhile, the higher accumulation of TPC $\Delta$ in the needles (up to $1.4 \mathrm{mg} / \mathrm{g}^{-1}$ ) (Figure $5 \mathrm{a}$ ) and in the roots (up to $0.8 \mathrm{mg} / \mathrm{g}^{-1}$ ) (Figure $5 \mathrm{c}$ ), associated with the higher resistance to the pathogen spread in the seedlings in the second half-sib Scots pine family and likely contributed to the incidence rate of H. annosum (Figure 2). The lowest incidence of pathogen was determined in the half-sib families with the highest accumulation of TPC $\Delta$ in roots two months after inoculation (No. 9, 1, and 2 half-sib families) (Figure 5c). The data obtained also showed that the mortality from H. annosum of these half-sib families were the lowest. Our results indicated that the highest mortality and incidence rate was in half-sib families (No. 3, 4, and 11) with low TPC in the roots six months after inoculation; however, these families had low pathogen spread.

\section{Discussion}

\subsection{Incidence Rate, Pathogen Spread, and Mortality Differences among Half-sib Families}

The genotypic variation among Scots pine half-sib families susceptibility to a pathogen in our study was expected. Previous studies showed that there is some evidence that differences in susceptibility against Heterobasidion might be found between Scots pines of different origins or provenances [24]. The incidence rate in inoculated half-sib families varied from 79\% (two months after inoculation) to $63 \%$ (ten months after inoculation), but no significant differences were found. Previous studies yielded a higher incidence rate, from 91\% in S-group isolates to 97\% in P isolates [61]. A study by Stenlid et al. [58] revealed that the incidence rate in intersterility group S varied from $56 \%$ to $70 \%$, while P-group from 92\% to 93\%. In another study [21] with P and S Heterobasidion isolates from live trees, the mean incidence of infection was $86 \%$ in pine and $100 \%$ in spruce. However, Heterobasidion isolates, isolated from stumps and dead trees, show a mean incidence rate of $96 \%$ and $98 \%$, respectively. In our investigation, isolates were grown from live Scots pine trees, and a pathogen intersterility group has not been identified.

Our findings show that pathogen spread in pine sapwood within inoculated half-sib families varied from 24-53 mm on average, but no significant differences among families were found. Pathogen spread was time dependent and quite slow; the maximum pathogen spread speed was approximately 5-7 $\mathrm{mm}$ in each inspection period and, in most of seedlings, the pathogen did not spread more than $5 \mathrm{~cm}$. The findings of Stenlid et al. [58] revealed that the maximum spread of mycelium in a pine stem was from 50-65 mm six weeks after inoculation. Research conducted by Zaluma et al. [24] revealed that the average pathogen spread in Scots pine wood was around $2 \mathrm{~cm}$ for $H$. annosum, and about $1 \mathrm{~cm}$ for $H$. parviporum per 122 days. Compared to Scots pine, the pathogen spread in Norway spruce was about four times greater [24]. Other studies supported the faster pathogen spread when comparing these two species $[21,57,58]$. It is known that S-group isolates easily infect spruce, but show limited growth on pine, whereas $\mathrm{P}$ isolates aggressively attack both hosts [21].

Our results show significant seedling mortality variance among half-sib families (from $1.3 \%-21.2 \%)$. Seedling dieback began seven months after inoculation with a spike at 9-10 months. A study conducted by Zaluma et al. [24] did not observe any pine seedlings' mortality 122 days after inoculation, nor did Stenlid et al. [58] six weeks after inoculation. Seedling mortality, as well as infection incidence rate, depends on the pathogen intersterility group. Werner and Lakomy [61] observed that the mortality of pine seedlings six months after inoculation was from 2.5\% (S-group isolates) to $5 \%$ ( $\mathrm{P}$ and $\mathrm{F}$ isolates). An even greater mortality in pine seedlings was found by Swedjemark et al. [21]; the mean seedling mortality was 37\%, in this investigation, the P strain killed about three times more seedlings compared to the $S$ strain. Werner and Lakomy [62] observed that all intersterility 
groups $(\mathrm{P}, \mathrm{S}, \mathrm{F})$ were more virulent on spruce than on pine, and the mean mortality in spruce was $53.91 \%$ and in pine $38.43 \%$. The same pattern has been observed in nature and in previous inoculation experiments where it was shown that the $\mathrm{P}$ group is generally more aggressive than the $\mathrm{S}$ in the aspect of sapwood growth extension and ability to kill its host $[58,63]$. The mortality differences in the studies may be determined by different seedlings susceptibility to the pathogen [64] and unequal pathogen virulence [65], incubation period [24,58], and plant defense mechanisms (secondary metabolites, phenolic compounds) [25-27]

\subsection{Infection-Induced Phenolic Response}

The Folin-Ciocalteu method has been widely used to determine the total concentration of phenols (TPC) occurring in plants [59]. Analysis of variance showed that the significant difference in TPC variation was observed in needles six months after inoculation (during the vegetation period), while in stems and roots this occurred two months after inoculation (during the dormancy period). The half-sib families (No. 2 and 9) with the lowest pathogen spread increased the accumulation of TPC in the roots two month after inoculation. Ganthaler and Mayr [66] revealed the seasonal variation and infection-induced changes in the accumulation of phenolic compounds. A study of Norway spruce resistant to Chrysomyxa rhododendri indicated that constitutive and early stage infection-induced concentrations of some phenolics strongly correlated with susceptibility and also reflected the levels of the tree's resistance [67]. Some authors noted that phenolic secondary compounds may limit the growth of rust fungi in Norway spruce and Melampsora in willow [68,69] immediately after infection and prevent the development of infection symptoms. Our results have shown that a greater reaction in the accumulation of TPC in inoculated Scots pine seedlings occurs six months after inoculation.

The TPC concentration comparison with susceptibility indicators (incidence rate, spread, and mortality) shows that the half-sib families with lower susceptibility were characterized by the ability to increase TPC after inoculation compared to the control group. The variation between different provenances and significant genetic regulation was reported for several stilbenes and flavonoids [41,70-72]. Venäläinen et al. [32] indicated that there are pronounced and significant differences in the concentration of individual stilbenes (PS and PSM) between the resistant and susceptible Scots pine hardwood of two progeny in Finland. According to Fossdal et al. [73], the trees showing low susceptibility may incorporate soluble phenolics into the cell wall to isolate the fungus by preventing nutrient uptake in the initial infection phase, thereby avoiding the development of disease symptoms [41]. In addition, they may activate a rapid modification of phenolics by isomerization, de-glycosylation, methoxylation, or oligomerization [27], resulting in higher concentrations of the active form. Furthermore, compounds may confer resistance as a group by synergistic effects [37] and the variability of the phenolic composition in time and space may challenge the fungus, as suggested for leaf-eating invertebrates [38]. Research conducted by Bonello et al. [74] revealed that other group of compounds, terpene concentrations in Italian stone pine shoots by stem induction with $H$. annosum represented the view that terpenoids are involved in localized resistance $[75,76]$ and may represent a first line of defense against fungal and insect attack, in addition to being involved in wound healing [77].

\section{Conclusions}

The genotypic variation among Scots pine half-sib families susceptibility to a pathogen were observed in our study. Seedling mortality due to $H$. annosum significantly differed among half-sib families; however, other susceptibility indicators (incidence rate and pathogen spread) did not show any significant differences. The phenolics profile of Scots pine half-sib families changed significantly in the needles during the growing season (from the sixth to the tenth month) and in the stems and roots during the dormancy period (from the moment of inoculation to the sixth month). Infection-induced responses of different half-sib families induced changes in the accumulation of TPC and influenced the values of susceptibility indicators, especially pathogen spread and mortality rate. Thus, it is likely 
that the lower susceptibility of Scots pine half-sib families is based on a combination of enhanced constitutive and inducible phenolic defense mechanisms. Our results may improve the physiological and biochemical understanding of pathogen defense in Scots pine half-sib families. The data may facilitate the selection of Scots pine half-sib families with low susceptibility for breeding programs and forest management strategies.

Author Contributions: Conceptualization, A.M., P.Ž., and V.B.; data curation, V.S.-Š., P.Ž., and V.B.; investigation, A.M., V.S.-Š., and P.Ž.; methodology, A.M., and V.S.-Š.; software, V.B.; visualization, V.B.; writing—original draft, A.M.; writing—review and editing, V.S.-Š., P.Ž., and V.B.

Funding: This research is funded by the European Social Fund under the No 09.3.3 - LMT - K - 712 "Development of Competences of Scientists, other Researchers and Students through Practical Research Activities" measure.

Conflicts of Interest: The authors declare no conflict of interest.

\section{References}

1. Mason, W.L.; Alia, R. Current and future status of Scots pine (Pinus sylvestris L.) forests in Europe. For. Syst. 2000, 1, 317-336.

2. ME/SFS (Ministry of Environment, State Forest Service). Lithuanian Statistical Yearbook of Forestry 2018; Butkus, A., Dumčienè, V., Eigirdas, M., Kuliešis, A., Vižlenskas, D., Eds.; Lututė: Kaunas, Lithuania, 2018.

3. Johannesson, H.; Stenlid, J. Nuclear reassortment between vegetative mycelia in natural populations of the basidiomycete Heterobasidion annosum. Fungal Genet. Biol. 2004, 41, 563-570. [CrossRef] [PubMed]

4. Woodward, S.; Stenlid, L.; Karjalainen, R.; Hüttermann, A. Heterobasidion annosum: Biology, Ecology, Impact and Control; CAB International: Wallingford, CT, USA, 1998; pp. 387-403.

5. ME/SFS (Ministry of Environment, State Forest Service). Lithuanian Statistical Yearbook of Forestry 2016; Butkus, A., Dumčienè, V., Eigirdas, M., Kuliešis, A., Vižlenskas, D., Eds.; Lututė: Lithuania, Kaunas, 2016.

6. Delatour, C.; von Weissenberg, K.; Dimitri, L. Host resistance. In Heterobasidion annosum: Biology, Ecology, Impact and Control; Woodward, S., Stenlid, J., Karjalainen, R., Hüttermann, A., Eds.; CAB International: Wallingford, UK, 1998; pp. 143-166.

7. Fiodorov, N.I. Eastern Europe and Baltic countries. In Heterobasidion Annosum: Biology, Ecology, Impact and Control; Woodward, S., Stenlid, J., Karjalainen, R., Hüttermann, A., Eds.; CAB International: Wallingford, UK, 1998; pp. 387-403.

8. Lygis, V.; Vasiliauskas, R.; Stenlid, J.; Vasiliauskas, A. Silvicultural and pathological evaluation of Scots pine afforestations mixed with deciduous trees to reduce the infections by Heterobasidion annosum s. For. Ecol. Manag. 2004, 201, 275-285. [CrossRef]

9. Stenlid, J.; Rönnberg, J.; Vollbrecht, G. Rutten forskning hjäl pers skogen. Skog Forsk. 2000, 1, 31-35. (In Swedish)

10. Thor, M. Heterobasidion Root Rot in Norway Spruce: Modelling Incidence, Control Efficacy and Economic Consequences in Swedish Forestry. Ph.D. Thesis, Swedish University of Agricultural Sciences, Uppsala, Sweden, 2005.

11. Swedjemark, G.; Karlsson, B. Genotypic variation in susceptibility following artificial Heterobasidion annosum inoculation of Picea abies clones in a 17-year-old field test. Scand. J. For. Res. 2004, 19, 103-111. [CrossRef]

12. Redfern, D.B.; Stenlid, J. Spore dispersal and infection. In Heterobasidion annosum: Biology, Ecology, Impact and Control; Woodward, S., Stenlid, J., Karjalainen, R., Huttermann, A., Eds.; CAB International: Wallingford, UK, 1998; pp. 105-124.

13. Hadfield, F.S.; Goheen, D.J.; Filip, G.M.; Schmitt, C.L.; Harvey, R.D. Root Diseases in Washington and Oregon Conifers; R6-FPM-250-86; USDA Forest Service, State and Private Forestry, Forest Pest Management: Portland, OR, USA, 1986.

14. Lygis, V.; Vasiliauskas, R.; Stenlid, J. Planting Betula pendula on pine sites infested by Heterobasidion annosum: Disease transfer, silvicultural evaluation, and community of wood-inhabiting fungi. Can. J. For. Res. 2004, 34, 120-130. [CrossRef]

15. Vasiliauskas, R.; Lygis, V.; Thor, M.; Stenlid, J. Impact of biological (Rotstop) and chemical(urea) treatments on fungal community structure in freshly Picea abies stumps. Biol. Control 2004, 31, 405-413. [CrossRef] 
16. Brandtberg, P.O.; Johansson, M.; Seeger, P. Effects of season and urea treatment on infection of stumps of Picea abies by Heterobasidion annosum in stands on former arable land. Scand. J. For. Res. 1996, 11, 261-268. [CrossRef]

17. Von Weissenberg, K. Variation in relative resistance to spread of Fomes annosus in four clones of Picea abies. Eur. J. For. Pathol. 1975, 5, 112-117. [CrossRef]

18. Swedjemark, G.; Stenlid, J. Variation in spread of Heterobasidion annosum in clones of Picea abies grown at different vegetation phases under greenhouse conditions. Scand. J. For. Res. 1996, 11, 137-144. [CrossRef]

19. Swedjemark, G.; Stenlid, J. Between-tree and between isolate variation for growth of S-group Heterobasidion annosum in sapwood of Picea abies cuttings. Can. J. For. Res. 1997, 27, 711-715. [CrossRef]

20. Skrøppa, T.; Solheim, H.; Steffenrem, A. Genetic variation, inheritance patterns and parent-offspring relationships after artificial inoculations with Heterobasidion parviporum and Ceratocystis polonica in Norway spruce seed orchards and progeny tests. Silva Fennica 2015, 49, 1191. [CrossRef]

21. Swedjemark, G.; Johannesson, H.; Stenlid, J. Intraspecific variation in Heterobasidion annosum for growth in sapwood of Picea abies and Pinus sylvestris. For. Pathol. 2008, 29, 249-258. [CrossRef]

22. Swedjemark, G.; Karlsson, B. Mycelial growth and exclusion of Heterobasidion parviporum inoculated in branches of 15-year-old Picea abies clones. Scand. J. For. Res. 2006, 36, 209-214. [CrossRef]

23. Oliva, J.; Gonthier, P.; Stenlid, J. Gene flow and inter-sterility between allopatric and sympatric populations of Heterobasidion abietinum and H. parviporum in Europe. For. Pathol. 2010, 41, 243-252. [CrossRef]

24. Zaluma, A.; Gailis, A.; Burnevica, N.; Korhonen, K.; Gaitnieks, T. Susceptibility of Picea abies and Pinussylvestris seedlings of various origins to Heterobasidion annosum and H. parviporum. Proc. Latv. Acad. Sci. Sect. B 2016, 70, 29-33. [CrossRef]

25. Hammerschmidt, R. Phenols and plant-pathogen interactions: The saga continues. Physiol. Mol. Plant Pathol. 2005, 66, 77-78. [CrossRef]

26. Witzell, J.; Martín, J.A. Phenolic metabolites in the resistance of northern forest trees to pathogens-past experience sand future prospects. Can. J. For. Res. 2008, 38, 2711-2727. [CrossRef]

27. Chong, J.; Poutaraud, A.; Hugueney, P. Metabolism and roles of stilbenes in plants. Plan Sci. 2009, 177, 143-155. [CrossRef]

28. Pan, H.; Lundgren, L.N. Phenolic extractives from root bark of Picea abies. Phytochemistry 1995, 39, $1423-1428$. [CrossRef]

29. Slimestad, R. Flavonoids in buds and young needles of Picea, Pinus and Abies. Biochem. Syst. Ecol. 2003, 31, 1247-1255. [CrossRef]

30. Sallas, L.; Kainulainen, P.; Utriainen, J.; Holopainen, T.; Holopainen, J.K. The influence of elevated O3 and $\mathrm{CO}_{2}$ concentrations on secondary metabolites of Scots pine (Pinus sylvestris L.) seedlings. Glob. Chang. Biol. 2001, 7, 303-311. [CrossRef]

31. Schultz, T.P.; Nicholas, D.D. Naturally durable heartwood: Evidence for a proposed dual defensive function of the extractives. Phytochemistry 2000, 54, 47-52. [CrossRef]

32. Venäläinen, M.; Harju, A.M.; Kainulainen, P.; Viitanen, H.; Nikulainen, H. Variation in decay resistance and its relationship with other wood characteristics in old Scots pines. Ann. For. Sci. 2003, 60, 409-417. [CrossRef]

33. Lieutier, F.; Sauvard, D.; Brignolas, F.; Picron, V.; Yart, A.; Bastien, C.; Jay-Allemand, C. Changes in phenolics metabolites of Scots pine induced by Ophiostomabrunneo-ciliatum, a bark beetle associated fungus. For. Pathol. 1996, 26, 145-216. [CrossRef]

34. Bois, E.; Lieutier, F. Phenolic response of Scots pine clones to inoculation with Leptographium wingfieldii, a fungus associated with Tomicus piniperda. Plant Physiol. Biochem. 1997, 35, 819-825.

35. Bonello, P.; Heller, W.; Sanderman, H. Ozone effects on root-disease susceptibility and defense responses in mycorrhizal and non-mycorrhizal seedlings of Scots pine (Pinus sylvestris L.). New Phytol. 1993, 124, 653-663. [CrossRef]

36. Bonello, P.; Blodgett, J.T. Pinus nigra-Sphaeropsis sapinea as a model pathosystem to investigate local and systemic effects of fungal infection of pines. Physiol. Mol. Plant Pathol. 2003, 63, 249-261. [CrossRef]

37. Wallis, C.; Eyles, A.; Chorbadjian, R.; McSpadden Gardener, B.; Hansen, R.; Cipollini, D.; Herms, D.A.; Bonello, P. Systemic induction of phloem secondary metabolism and its relationship to resistance to a canker pathogen in Austrian pine. New Phytol. 2008, 177, 767-778. [CrossRef] [PubMed] 
38. Edenius, L.; Grzegorz, M.; Witzell, J.; Berghd, J. Effects of repeated fertilization of young Norway spruce on foliar phenolics and arthropods: Implications for insectivorous birds' food resources. For. Ecol. Manag. 2012, 277, 38-45. [CrossRef]

39. Andrew, R.L.; Wallis, I.R.; Harwood, C.E.; Henson, M.; Foley, W.J. Heritable variation in the foliar secondary metabolite sideroxylonal in Eucalyptus confers cross-resistance to herbivores. Oecologia 2007, 153, 891-901. [CrossRef]

40. Külheim, C.; Yeoh, S.H.; Wallis, I.R.; Laffan, S.; Moran, G.F.; Foley, W.J. The molecular basis of quantitative variation in foliar secondary metabolites in Eucalyptus globulus. New Phytol. 2011, 191, 1041-1053. [CrossRef] [PubMed]

41. Ganthaler, A.; Stoggl, W.; Mayr, S.; Kranner, I.; Schuler, S.; Wischnitzki, E. Association genetics of phenolic needle compounds in Norway spruce with variable susceptibility to needle bladder rust. Plant Mol. Biol. 2017, 94, 229-251. [CrossRef] [PubMed]

42. González-Martínez, S.C.; Wheeler, N.C.; Ersoz, E.; Dana Nelson, C.; Neale, D.B. Association genetics in Pinus taeda L. I. Wood property traits. Genetics 2007, 175, 399-409. [CrossRef] [PubMed]

43. Dillon, S.K.; Nolan, M.; Li, W.; Bell, C.; Wu, H.X.; Southerton, S.G. Allelic variation in cell wall candidate genes affecting solid wood properties in natural populations and land races of Pinus radiata. Genetics 2010, 185, 1477-1487. [CrossRef] [PubMed]

44. Beaulieu, J.; Doerksen, T.; Boyle, B.; Clément, S.; Deslauriers, M.; Beauseigle, S.; Blais, S.; Poulin, P.L.; Lenz, P.; Caron, S.; et al. Association genetics of wood physical traits in the conifer white spruce and relationships with gene expression. Genetics 2011, 188, 197-214. [CrossRef] [PubMed]

45. Westbrook, J.W.; Resende, M.F.R.; Muñoz, P.D.R.; Walker, A.R.; Wegrzyn, J.L.; Nelson, C.D.; Neale, D.B.; Kirst, M.; Huber, D.A.; Gezan, S.A.; Peter, G.F.; et al. Association genetics of oleoresin flow in loblolly pine: Discovering genes and predicting phenotype for improved resistance to bark beetles and bioenergy potential. New Phytol. 2013, 199, 89-100. [CrossRef] [PubMed]

46. Lepoittevin, C.; Harvengt, L.; Plomion, C.; Garnier-Géré, P. Association mapping for growth, straightness and wood chemistry traits in the Pinus pinaster Aquitaine breeding population. Tree Genet. Genom 2012, 8 , 113-126. [CrossRef]

47. Budde, K.B.; Heuertz, M.; Hernández-Serrano, A.; Pausas, J.G.; Vendramin, G.G.; Verdú, M.; González-Martínez, S.C. In situ genetic association for serotiny, a fire-related trait, in Mediterranean maritime pine (Pinus pinaster). New Phytol. 2014, 201, 230-241. [CrossRef] [PubMed]

48. González-Martínez, S.C.; Huber, D.; Ersoz, E.; Davis, J.M.; Neale, D.B. Association genetics in Pinus taeda L. II. Carbon isotope discrimination. Heredity 2008, 101, 19-26. [CrossRef]

49. Cumbie, W.P.; Eckert, A.; Wegrzyn, J.; Whetten, R.; Neale, D.; Goldfarb, B. Association genetics of carbon isotope discrimination, height and foliar nitrogen in a natural population of Pinus taeda L. Heredity 2011, 107, 105-114. [CrossRef]

50. Eckert, A.J.; Bower, A.D.; Wegrzyn, J.L.; Pande, B.; Jermstad, K.D.; Krutovsky, K.V.; St Clair, J.B.; Neale, D.B. Association genetics of coastal Douglas fir (Pseudotsuga menziesii var. menziesii, Pinaceae). I. Cold-hardiness related traits. Genetics 2009, 182, 1289-1304. [CrossRef] [PubMed]

51. Holliday, J.A.; Ritland, K.; Aitken, S.N. Widespread, ecologically relevant genetic markers developed from association mapping of climate related traits in Sitka spruce (Picea sitchensis). New Phytol. 2010, 188, 501-514. [CrossRef] [PubMed]

52. Eckert, A.J.; Wegrzyn, J.L.; Cumbie, W.P.; Goldfarb, B.; Huber, D.A.; Tolstikov, V.; Fiehn, O.; Neale, D.B. Association genetics of the loblolly pine (Pinus taeda, Pinaceae) metabolome. New Phytol. 2012, 193, 890-902. [CrossRef] [PubMed]

53. Quesada, T.; Gopal, V.; Cumbie, W.P.; Eckert, A.J.; Wegrzyn, J.L.; Neale, D.B.; Goldfarb, B.; Huber, D.A.; Casella, G.; Davis, J.M. Association mapping of quantitative disease resistance in a natural population of loblolly pine (Pinus taeda L.). Genetics 2010, 186, 677-686. [CrossRef] [PubMed]

54. Swedjemark, G.; Stenlid, J. Population dynamics of the root rot fungus Heterobasidion annosum following thinning of Picea abies. Oikos 1993, 66, 247-254. [CrossRef]

55. Stenlid, J. Population structure of Heterobasidion annosum as determined by somatic incompatibility, sexual incompatibility, and isoenzyme patterns. Can. J. Bot. 1985, 63, 2268-2273. [CrossRef]

56. Johannsson, M.; Stenlid, J. Infection of roots of Norway spruce (Picea abies) by Heterobasidion annosum. Eur. J. For. Pathol. 1985, 15, 32-45. [CrossRef] 
57. Swedjemark, G.; Stenlid, J. Susceptibility of conifer and broadleaf seedlings to Swedish S- and P-strains of Heterobasidion annosum under greenhouse conditions. Plant Pathol. 1995, 44, 73-79. [CrossRef]

58. Stenlid, J.; Swedjemark, G. Differential growth of S- and P-isolates of Heterobasidion annosum in Picea abies and Pinus sylvestris. Trans. Br. Mycol. Soc. 1988, 90, 209-213. [CrossRef]

59. Singleton, V.L.; Orthofer, R.; Lamuela-Raventos, R.M. Analysis of total phenols and other oxidation substrates and antioxidants by means of Folin-Ciocalteu reagent. Methods Enzymol. 1999, 299, 152-178. [CrossRef]

60. Kenward, M.G.; Roger, J.H. Small Sample Inference for Fixed Effects from Restricted Maximum Likelihood. Biometrics 1997, 53, 983-997. [CrossRef] [PubMed]

61. Werner, A.; Lakomy, P. Host specialization of IS-group isolates of Heterobasidion annosum to Scots pine, Norway spruce and common fir in field inoculation experiments. Dendrobiology 2002, 47, 59-68.

62. Werner, A.; Lakomy, P. Intraspecific variation in Heterobasidion annosum for mortality rate on Pinus sylvestris and Picea abies seedlings grown in pure culture. Mycologia 2002, 94, 856-861. [CrossRef]

63. Stenlid, J. Controlling and predicting the spread of Heterobasidion annosum from infected stumps and trees of Piceaabies. Scand. J. For. Res. 1987, 2, 187-198. [CrossRef]

64. Swedjemark, G.; Stenlid, J.; Karlsson, B. Variation in growth of Heterobasidion annosum among clones of Picea abies incubated for different periods of time. For. Pathol. 2001, 31, 163-175. [CrossRef]

65. Lakomy, P.; Kwasna, H.; Dalke-Swiderska, M. The virulence of Heterobasidion parviporum population from Norway spruce stand in Suvalki forest district. Acta Sci. Polon. Silvarum Colendarum Ratio Ind. Lig. 2011, 10, 27-36.

66. Ganthaler, A.; Mayr, S. Temporal variation in airborne spore concentration of Chrysomyxa rhododendri: Correlation with weather conditions and consequences for Norway spruce infection. For. Pathol. 2015, 45, 443-449. [CrossRef]

67. Ganthaler, A.; Stöggl, W.; Kranner, I.; Mayr, S. Foliar Phenolic Compounds in Norway Spruce with Varying Susceptibility to Chrysomyxa rhododendri: Analyses of Seasonal and Infection-Induced Accumulation Patterns. Front. Plant Sci. 2017, 8, 1173. [CrossRef] [PubMed]

68. Hakulinen, J.; Sorjonen, S.; Julkunen-Tiitto, R. Leaf phenolics of three willow clones differing in resistance to Melampsora rust infection. Physiol. Plant 1999, 105, 662-669. [CrossRef]

69. Hjältén, J.; Niemi, L.; Wennström, A.; Ericson, L.; Roininen, H.; Julkunen-Tiitto, R. Variable responses of natural enemies to Salix triandra phenotypes with different secondary chemistry. Oikos 2007, 116, 751-758. [CrossRef]

70. Slimestad, R. Amount of flavonols and stilbenes during needle development of Picea abies; variation between provenances. Biochem. Syst. Ecol. 1998, 26, 225-238. [CrossRef]

71. Evensen, P.C.; Solheim, H.; Hoiland, K.; Stenersen, J. Induced resistance of Norway spruce, variation of phenolic compounds and their effects on fungal pathogen. For. Pathol. 2000, 30, 97-108. [CrossRef]

72. Lieutier, F.; Brignolas, F.; Sauvard, D.; Yart, A.; Galet, C.; Brunet, M.; van de Sype, H. Intra- and inter-provenance variability in phloem phenols of Picea abies and relationship to a bark beetle-associated fungus. Tree Physiol. 2003, 23, 247-256. [CrossRef] [PubMed]

73. Fossdal, C.G.; Nagy, N.E.; Hietala, A.M.; Kvaalen, H.; Slimestad, R.; Woodward, S.; Solheim, H. Indications of heightened constitutive or primed host response affecting the lignin pathway transcripts and phenolics in mature Norway spruce clones. Tree Physiol. 2012, 32, 1137-1147. [CrossRef] [PubMed]

74. Bonello, P.; Capretti, P.; Luchi, N.; Martini, V.; Michelozzi, M. Systemic effects of Heterobasidion annosums. s. infection on severity of Diplodia pinea tip blight and terpenoid metabolism in Italian stone pine (Pinus pinea). Tree Physiol. 2008, 28, 1653-1660. [CrossRef] [PubMed]

75. Lieutier, F.; Garcia, J.; Romary, P.; Yart, A.; Jactel, H.; Sauvard, D. Inter-tree variability in the induced defense reaction of Scots pine to single inoculations by Ophiostomabrunneo-ciliatum, a bark beetle-associated fungus. For. Ecol. Manag. 1993, 59, 257-270. [CrossRef]

76. Schmidt, A.; Zeneli, G.; Hietala, A.M.; Fossdal, C.G.; Krokene, P.; Christiansen, E.; Gershenzon, J. Induced chemical defenses in conifers: Biochemical and molecular approaches to studying their function. In Chemical Ecology and Phytochemistry of Forest Ecosystems; Romeo, J., Ed.; Elsevier: Amsterdam, The Netherlands, 2005; pp. 1-28.

77. Phillips, M.A.; Croteau, R.B. Resin-based defenses in conifers. Trends Plant Sci. 1999, 4, 184-190. [CrossRef] 
(C) 2019 by the authors. Licensee MDPI, Basel, Switzerland. This article is an open access article distributed under the terms and conditions of the Creative Commons Attribution (CC BY) license (http:/ / creativecommons.org/licenses/by/4.0/). 